\title{
Internationalization, Whiteness, and Biopolitics of Higher Education
}

\author{
Tatiana Suspitsyna \\ The Ohio State University, USA
}

\begin{abstract}
From a postcolonial perspective, U.S. higher education is entangled with the colonial past and the neoliberal neo-colonial present as an economic actor that dominates global educational markets through internationalization. The COVID pandemic and the nationwide movement for racial justice have brought these entanglements into stark relief in the ways U.S. colleges and universities are implicated in the neoliberal biopolitics of race. Applied to higher education, Michel Foucault's concept of biopolitics as the management of life and wellbeing of populations and his conceptualization of racism as a biopolitical tool illuminate how U.S. colleges and universities maintain racialized categorizations of lives worth protecting and lives considered disposable in the service of dominant whiteness. De-centering whiteness and eliminating its advantage and superiority in research, curricula, instruction, and internationalization is a necessary step toward a future that envisions a more inclusive and equal citizenship.
\end{abstract}

Keywords: internationalization, higher education, neocolonialism, biopower, biopolitics, whiteness, racism, citizenship

The virulent spread of COVID-19 and the world's governments' dramatic measures to curtail the pandemic halted most international mobility of students and scholars and put a pause on many educational and research activities. Observers of higher education in the U.S. predicted increasingly digitized futures of college teaching (Kim, 2020) and losses in universities' revenues from international students and federal research funding (Ellis, 2020), and social scientists and philosophers rediscovered the startling relevance of Michel Foucault's writings on biopower and biopolitics. The global ubiquity of population control measures during this pandemic was seen as evidence of the "constant deployment of biopolitics" (Esposito, 2020, 
para 2) or, in Bruno Latour's more colorful language, as "a caricatured form of the figure of biopolitics that seems to have come straight out of a Michel Foucault lecture" (Latour, 2020, para 4).

At the same time, a second disease, "a racism pandemic" came to the forefront of the public discussion in the U.S. following the murder of George Floyd and the nationwide eruption of protests against racial injustice and police brutality (American Psychological Association, 2020, May 29). Universities that until then had been reluctant to remove statues commemorating defenders of slavery began to dismantle them hastily, and college presidents who had previously showed little support for Black Lives Matter now spoke of their sympathy and solidarity (Mangan, 2020, June 8 ). The harassment of and violence against Black bodies that had appeared with regularity in the news spurred analyses of the biopolitics of death, or as Achille Mbembe (2003) called it, "necropolitics" in the service of white supremacy (Apata, 2020; Bowman, 2020). Describing white supremacy as a taken-for-granted, systemic privileging and superiority of white subjects (Ansley, 1997), critical scholars of education yet again offered analyses of the impact of pervasive racism and white supremacy on policy making and outcomes in higher education (Cabrera, 2020).

With biopolitics loosely defined as the management of life and wellbeing of populations (Foucault, 1975-1976/2003), the purpose of this conceptual paper is to explore the roles of higher education and internationalization in biopolitics during and outside the coronavirus pandemic. The inquiry is guided by two questions: How is U.S. higher education experiencing and participating in the biopolitics of the current moment? And how do higher education and internationalization engage with whiteness as a biopolitical category? In the Global North, educational institutions at all levels serve as conduits and agents of biopolitics by managing and shaping the younger generations of citizens through pedagogy and curriculum (Bourassa, 2011), control and surveillance (Hope, 2014) and the privileging of white, western, neoliberal epistemologies and ontologies over others (Gyamera \& Burke, 2015; Bourassa, 2019). Therefore, at its heart, this inquiry about the present and future of higher education and internationalization aims to explore larger issues of the limitations and promises of the United States citizenship and global positioning as they are envisioned and cultivated by colleges and universities.

The paper begins with a discussion of the colonial past and neoliberal present of U.S. higher education that shape contemporary universities' neo-colonial agendas and embrace internationalization as a vehicle of Eurocentrism and white domination. Next, the theoretical framework of the paper introduces Foucault's concepts of biopower and biopolitics and supplements them with postcolonial critiques of Foucault's account of state racism. The following two sections examine U.S. higher education in the biopolitics of the present moment and trace the current engagement of higher education and internationalization with whiteness as a central characteristic of normative citizenship. Finally, the concluding section restates the importance of higher education's involvement in correcting the biopolitics of race and expresses hope in affirmative biopolitics for the purpose of the common good. 


\section{LITERATURE REVIEW: UNIVERSITIES AND INTERNATIONALIZATION AS NEOCOLONIAL PROJECTS}

From the start of American colonies, higher education, along with the church and state, aimed to build a nation whose European history, learning, and knowledge would replace and erase the presence, knowledges, and lived experience of Indigenous peoples (Patel, 2014). European colonization itself was predicated on the ideas of the superiority and universality of western knowledge and ways of knowing, which formed the ideological foundation of modernity at the end of the Renaissance and which were later inherited, reinforced, and spread by capitalism (Stein \& Andreotti, 2017). To benefit from colonial exploitation, capitalism relied on knowledge that "justified racism and the inferiority of human lives that were naturally considered dispensable" (Mignolo, 2011, p. 6). Thus rooted in the colonial history of the subjugation of Indigenous and Black people (Stein, 2020), U.S. colleges and universities continue to be dominated by whiteness in their academic norms and traditions, composition of the professoriate and high-level administration, campus culture, and climate (Cabrera et al., 2017). It is in this sense that universities, dominated by whiteness and practicing market approaches, can be said to continue the modern/colonial project (Andreotti et al., 2015; Stein \& Andreotti, 2017).

The entanglement of education with neoliberal capitalism--an advanced form of capitalism marked by increasing privatization and a shrinking welfare state - and colonialism is well documented. Driven by neoliberal economic logics, universities exploit Black students in college athletics and campus diversity ads and depend on Black faculty's labor in supporting diversity without challenging the overall systemthe relationships that Squire, Williams, and Tuitt (2018) call "plantation politics." Universities assimilate the work of their scholars of color to signify inclusivity, all the while maintaining market-driven policies and practices that disadvantage people of color (Kidman, 2020). Underlying the neoliberal reforms aimed to reduce gaps between white students and students of color, the "cultural deficit ideology" draws on the colonial premise of the superiority of white culture (Ahlquist, 2011, p. 9). The neoliberal movement for evidence-based education is permeated by colonial discourses on the civilizing power of western science (Shahjahan, 2011). Although exploitation of people of color and the ideology of white supremacy chronologically predate neoliberalism, it is in neoliberalism that these practices and ideas become encoded in educational policy and practice for the specific purpose of generating economic advantage for higher education institutions. The utilization of racist policies and practices for market purposes is reflective of the changed relationship between the state and the market. Whereas classical liberalism strived to free the market from the inference by the state, neoliberalism wants the state to be active in creating conditions favorable for the market (Olssen \& Peters, 2005). As a result, racial hierarchies and colonial discourses embedded in economic relations are preserved and reproduced as necessary conditions for a free market by the state and universities alike.

Beneficiaries of colonialism in the past and its legacy in the present, U.S. colleges and universities are frequently criticized as agents of neo-colonization through 
internationalization. For practitioners, internationalization is operationalized as the "process of integrating an international, intercultural, and global dimension into the purpose, function or delivery of post-secondary education" (Knight 2004, p. 11). For scholars, internationalization is conceptualized at the intersection of globalization, neoliberalism, and colonialism. The links between internationalization and neoliberal globalization have been variously interrogated and extolled. Because globalization is "associated with the actions and interests of transnational corporations, the workings of global financial and labor markets, the development of new forms of production based on new technologies, and the compression of time and space" (Naidoo, 2011, p. 42), it is an effective spreader of neoliberal market ideology worldwide. In this light, internationalization has long been valued as "the engine of globalization" that drives individuals and institutions to pursue benefits across national borders (Mitchell $\&$ Nielsen 2012, p. 10) and critiqued for its unproblematic acceptance of neoliberal globalization as inevitable and appropriate (Stein, 2017).

The link between internationalization and colonization has been examined largely from postcolonial perspectives. Reflecting on the colonial justifications of internationalization produced by Europeans in Asia, Kazuhiro Ebuchi observed that in a nation with a hegemonic role in the world order, internationalization works as a transitive verb always requiring a target of action, a role which a smaller nation is forced to accept (Ebuchi as cited in Deem et al., 2008). This asymmetry in the effects of internationalization and the fact that the economic power and influence still reside with former colonizing nations compel critics to view internationalization as a form of re- or neocolonization. For example, in their quest for competitiveness and global recognition, many South American universities embrace the accountability and quality assurance discourses and practices of their northern neighbors at the expense of their local knowledges and traditions (Blanco Ramirez, 2014). Pursuing the status of the "world-class" university, some Asian higher education institutions that had previously fought against colonial influences, are now dependent on U.S. standards, instruction in English, and the adoption of western curricula (Deem et al., 2008). The privileging of western knowledge and cultural capital as profitable in internationalization as a whole suggests that internationalization operates as a vehicle for spreading and structuring whiteness (Johnstone \& Lee, 2020). The predominantly white elite academic networks in the Global North and South have a vested interest in dominating local (Eurocentric) knowledge production and publication and can easily hollow out the postcolonial critiques of internationalization as irrelevant or harmful to the non-western nations' prospects of increasing their visibility and participation in the global production of research (Dutta, 2020).

The global neoliberal rationality that compels scholars and students in nonwestern nations to internationalize by imitating western norms, laws, and practices for economic advantage is an example of what Foucault termed governmentality (Suspitsyna, 2015). Governmentality and its related concept of biopower illuminate what universities do to manage, develop, direct, and monitor their students and employees during and outside the COVID pandemic. 


\section{THEORETICAL FRAMEWORK: BIOPOWER, NECROPOLITICS, AND RACISM}

Michel Foucault's concepts of biopower and governmentality are often used complementarily. Foucault (1977-1978/2007) conceptualized governmentality as a political rationality aimed at managing the welfare of populations, whereas by biopower he meant a technology to manage living human beings not as individuals but as "a global mass that is affected by overall processes characteristic of birth, death, production, illness, and so on" (Foucault 1975-1976/2003, pp. 243-244). Foucault observed how vividly, at the start of modernity, biopower was manifested in the European colonization of the continents and the ensuing violence against people of different races. He concluded that colonization, racism, and wars in the history of Europe were connected to the exercise of biopower aimed at protecting, purifying, and regenerating one's own race and acting as an apparatus of security (Foucault $1975-1976 / 2003$, p. 257). In other words, the state reserved for itself the right to separate people into those whose life is worth being protected and those whose life is disposable and should be repudiated making racism "the precondition that makes killing acceptable" (Foucault 1975-1976/2003, p. 256).

As Foucault's understanding of racism is not confined to a biological meaning, scholars used his work to examine how race defined as "intrinsic cultural differences" has served as a pretext to wage wars (Fiaccadori, 2015). His account of state racism as emanating from the modern European state's preoccupation with identifying and annihilating threat to its (white) population has also been used productively in research on state control over migrant populations in the name of health security (Voelkner 2011), western interventions in the name of global security after September 11, 2001 (Reid 2005), and anti-Black racism in the U.S. (Winnubst, 2020). In educational research specifically, biopolitics has been used to examine the racialization of student intelligence assessments (Lewis, 2009), development theories in education (Sonu, 2020) and special education and students with disabilities (Kearl, 2019). Most recently, the lockdown and stay-at-home measures instituted by many nations provoked a vigorous discussion about the biopolitics of the coronavirus pandemic (Demetri, 2020; Esposito, 2020; Latour, 2020; Wuest, 2020), although the long-term effects of those biopolitical moves on higher education and internationalization remains unclear.

Although Marxists have long been critical of Foucault's neglect of economic development (Olssen, 2004), it is postcolonial critics of biopower who note the Eurocentrism of Foucault's work and his failure to consider the fundamental role of slavery in creating wealth accumulation as well as financial and legal institutions that gave rise to capitalism in the modern state (Howell \& Richter-Montpetit, 2019). They also maintain that from its inception, the United States practiced racial dividing that separated what was considered the superior population from "the economically deprived and evincing the effects of that deprivation" such as ill health, poverty, violence, and poor education and that "racism - not just racial slavery-was enshrined in its laws from its very beginning" (McWhorter, 2010, p. 77). Reflecting on colonial violence against enslaved people, Achille Mbembe (2003) coined the term necropolitics as a kind of biopolitics directed at the extermination of groups of people 
through killing or creating intolerable conditions of existence that lead to their disease and death or, as Mbembe (2003) called them, "death-worlds", "new and unique forms of social existence in which vast populations are subjected to conditions of life conferring upon them the status of living dead" (p. 40). More recently, this focus on the necropolitical effects of biopower has been extended to the analyses of the violence against Black and Brown bodies in the U.S. (Evans-Winters, 2017) and to pedagogical approaches to discussing violence against migrants and refugees (Zembylas, 2020).

The understanding of racism as a biopolitical tool that maintains the dominance of white culture, experience, and knowledge is essential to the discussion of higher education in this paper. Necropolitics as a form of biopower designed to harm and annihilate populations deemed unworthy of protection is equally illuminating in application to U.S. colleges and universities' reactions to the pandemic and protests against racial injustice.

\section{DISCUSSION}

\section{Higher Education in the Biopolitical Present}

Biopolitical analyses of higher education include examinations of various applications of political rationality aimed at investing in the life of multiple groups of people: students, faculty, staff, citizens, etc. In the application of biopolitical logic to the "knowledge economy," the emphasis on publications and grants produces overstressed and overworked bodies of academics (Allen \& Rasmussen, 2015) and contributes to what D'Hoest and Lewis (2015) call the "fatigue university." The tiredness and exhaustion are not only a byproduct of the publication regime but also a constitutive part of academic life, a necessary illness that describes what it means to be a faculty member (D'Hoest \& Lewis, 2015). In the biopolitics of managing student populations, standardized college admissions tests serve as a tool for categorizing students into hierarchies of achievement based on their racial, ethnic, and gender identities and parental education. Far from being an objective instrument external to the conditions that produce and maintain racialized, gendered, and classed achievement gaps, college admissions testing is part of a larger apparatus of measurement that is enmeshed in sociopolitical, economic, and cultural environments, policy contexts, and the testing preparation industry, all of which act upon and enact that hierarchized difference under the guise of educational equity (Dixon-Román, 2017).

Permeating U.S. college curricula, biopolitical logics aim at creating subjects of neoliberal market democracy dominated by whiteness. Pedagogical innovations in the scholarship of teaching and learning aim at transforming students and faculty into "entrepreneurial learners" who consume and utilize knowledge for competitive advantage (Servage, 2009). In science education in particular, the end goal is to create de-politicized citizens who are best prepared to function in a neoliberal market economy and to contribute to the country's fiscal health and global competitiveness (Bazzul, 2017; Hoeg \& Bencze, 2017). In teacher preparation, biopower manifests itself in defining a good teacher of color as a role model who overcame deficiencies 
of their race and ethnicity, thereby re-centering normative whiteness (Phillips \& Nava, 2011). Through educational discourses at all levels from primary to postsecondary, biopolitical logics and governmentality shape, describe, and prescribe what it means to be a U.S. citizen, a construct that beyond nationality and democratic participation includes the normative attributes of a citizen-subject: whiteness and masculinity (Cary, 2001) as well as middle classness, heterosexuality, and ablebodiedness (Brandzel, 2016).

The universities are also implicated in the darker side of biopolitics - what Henry Giroux called the biopolitics of disposability in relation to the lives and livelihoods of people of color $(2006 ; 2008)$ and what Daniele Lorenzini $(2020)$ today describes as biopolitics of differential vulnerability. Understanding racism as a form of biopower, Lorenzini points out that during the pandemic, the decisions about who stays in the protective environment of one's home and who is required to come to work involves racial and class categorizations. On college campuses nationwide, the frontline workers--custodians, dining hall employees, residence hall housekeepers, and so on - are the most racially diverse group of employees in higher education whose health and wellbeing are most at risk due to the lack of personal protective equipment and unsafe working conditions (Johnson \& Patel, 2020, August 19). Their fears of contagion and death in the service of the privileged college youth (DouglasGabriel, 2020, August 4) are rooted in their tacit understanding of the necropolitical institutional rationale that puts the comfort and safety of predominantly white middleclass students over the lives of working-class, ethnically diverse support staff. Furthermore, compared to white students, students of color are more vulnerable during the pandemic because of the triple impact of COVID, the psychological stress of racial injustice, and financial insecurity (Harvard T. H. Chan School of Public Health, 2020, October 29). Deemed disposable in the necropolitics of white supremacy, these students' lives are in danger from police brutality, racially biased health care, and invisibility to predominantly white faculty and administrators.

The role of higher education institutions in guarding the boundaries of citizenship is especially visible in international education, where international student mobility is implicated in immigration regimes and tied to discussions of who qualifies to become a U.S. citizen (Ritter \& Roth, 2021). Biopolitical considerations of preserving the dominance of white knowledge and culture are encoded in legal and policy frameworks that seek to regulate the demographic profile of incoming international students. For instance, in January 2017, President Trump's ban on travel from seven majority-Muslim countries signified a remarkably overt biopolitical move to formulate threat to the United States in racial and religious terms. Although most universities were quick to express their "shock, despair, and outrage" (Brown \& Najmabadi 2017), the racialized nature of the ban and the default whiteness of the nation it had been designed to protect escaped those responses (Stein, 2018). Given the fact that eight out of top 25 leading places of origin of international students in the U.S. are Muslim-majority nations (Open Doors, 2020), the ban provoked anxiety among doctoral students not only from the prohibited countries but also from other nations, causing them to fear changes in the visa regimes and to question their postgraduation employment plans in the country where their identity may be deemed undesirable (Todoran \& Peterson, 2020). 
Three years later, the COVID-19 pandemic occasioned a slew of other biopolitical measures, some of which were directly related to maintaining the supremacy of whiteness at the core of the national identity. Trump's insistent calling of the disease a "Wuhan virus" or "Chinese virus" cast Asians and Asian Americans as the Other, invoking the colonial imagery of the Yellow Peril (Webel, 2020) and in case of Asian Americans, the racist trope of the "perpetual foreigner" (Lee \& Waters, 2020; Suspitsyna \& Shalka, 2019). ver half a million Asian international students who were enrolled n U.S. colleges and universities, including over 372,000 students from China (Open Doors, 2020) could not but feel the consequences of that rhetoric. With the rise of discrimination, microaggressions, and open acts of hostility against Asian Americans and international students from Asia, college campuses struggled to provide counseling to these students because the existing trauma-based interventions are centered on white cultural norms and experiences (Litam, 2020). The wide scale and similarity of the attacks against Asians in Europe, Australia, and Canada illuminates that whiteness is not contained to national borders but is an international phenomenon (Nakayama, 2020).

\section{Engagement with Whiteness}

The COVID-19 pandemic, the social movements for racial justice, and more recently, the assault on the U.S. Capitol by a violent mob of President Trump supporters cast a piercing light on the problems of the supremacy of western knowledge and whiteness. Faced with racial reckoning and accountable for their own inability or unwillingness to engage with white supremacy, U.S. colleges and universities should no longer be able to claim innocence (McGuire, 2021). The reckoning involves acknowledging the biopolitical role of the U.S. academia in producing knowledge that "rest[s] on the racial statecraft, militarized science, and enduring notions of civilizational superiority" (Chatterjee \& Mayra, 2014, p. 14). Similarly, the post-pandemic recovery of internationalization offers an opportunity to "unsettle the colonial modes of thinking" that marginalize non-western knowledge, although there is yet little evidence that universities are planning to do so (Rizvi, 2020, p. 1316).

With its colonial entanglements in the past and neocolonial impulses in the present, internationalization of higher education in the U.S. requires a critical lens through which the centrality of whiteness in international education and knowledge production can be documented, analyzed, and dismantled. In her cartography of universities' approaches to internationalization, Stein (2017) found that most universities espoused soft critiques of internationalization, while only a small group adopted radical or liminal critical positions, challenging the neocolonial and neoliberal capitalist foundations of internationalization. Some fields, like business management and economic professions, in their unabashed embrace of neoliberal capitalism, continue to lead in internationalization centered on western knowledge and practice (Zapp \& Lerch, 2020). Espousing a more culturally sensitive approach, other communities such as international higher education professionals nevertheless lack a collective stance on global power differentials (Buckner \& Stein, 2019). Even student affairs professionals who work toward social change against racism and 
colonization as forms of oppression (e.g., Yakaboski \& Perozzi, 2018) define global learning from a U.S.-centric perspective. The desire to open, if not overcome, that perspective and to battle the parochialism of U.S. universities appears to be a popular rationale for internationalization in North America (Buckner, 2019). Coupled with the need to prepare graduates for a competitive global market, the discomfort with parochialism suggests the U.S. universities' anxiety about losing hegemony and missing out on the benefits of global engagement (Buckner, 2019).

In short, U.S. institutions of higher education are either oblivious of the full effect of their neocolonial presence globally or able to ignore it to reap the benefits of their location at the central nodes of the world's knowledge production. Internationalization remains essentially a westernization project that brings Eurocentric innovations in research, pedagogy, and instruction to indigenous universities by U.S. partners (Sperduti, 2017). Yet, more non-western countries strategically invest in research and development now, catching up with their wealthy counterparts in science productivity in selected fields (Gonzales-Brambila et al., 2016), and the flows of innovation and knowledge no longer move solely southwards on the Global North-South axis. Research suggests that today international collaborations follow a multipolar model, connecting multiple locations in the Global North and South, although the unequal power distribution still privileges the wealthier northern partners in the setting of research agendas (Pineda et al., 2020). At the same time, the United States is losing its share of international student mobility to other global destinations within and outside of the Anglophone world (Johnson, 2020). The domination of the English language and Anglophone scholarship in international research and education is increasingly problematized as intellectually limiting, epistemologically exclusionary, and undemocratic (Singh et al., 2018). International students attending western universities demand "epistemic democracy" to recognize their intellectual traditions and decolonize the host institutions' curricula and instruction (Hayes, 2020). Some scholars directly name racism as a fundamental problem of internationalization of Anglo-American education (Singh et al., 2018).

Yet, engagement with whiteness as a biopolitical category is essential for the ability of higher education to fulfil its role in educating citizens. Because whiteness is the key characteristic of the privileged citizen-subject in western societies (Brandzell, 2016), an interrogation of the racialization of people of color and normalization of the white experience in U.S. higher education and internationalization is an effort in re-imagining U.S. citizenship. The de-centering of whiteness as a biopolitical category worth defending is fraught with other profound revisions, such as de-normalization of privilege based on maleness, heterosexuality, and ablebodiedness, among others, in scholarly spaces, global academic communities, and society at large. As Amy Brandzell (2016) observes, stripped of their normative status, white subjectivities fight back to restore it by appealing to the idyllic past that they believe has been lost to them. "Hence," she concludes, "the narrative of sorrow and injury justifies the need for a 'cultural defense' in which the violence against immigrants, Natives, queers, people of color, and gender-variant others is legitimated in the name of protection" (Brandzell, 2016, p. 3). Thus, the cultural defense of white heritage can easily take the form of necropolitics against the Others who are seen as a threat to that heritage. 
White racial resentment at that perceived injury has a documented negative impact on a wide array of higher education issues ranging from funding (Taylor, et al., 2019) to college admissions (Moses et al., 2017) and college athletics (Wallsten et al., 2017). That speaks both to the importance of higher education in maintaining white supremacy and the opportunity for higher education institutions to engage in dismantling it. Contrary to the popular institutional position of neutrality and objectivity, this engagement requires re-politicization of universities and their explicit recognition of their role in correcting or abetting social ills (Karter et al., 2020). Repoliticization of internationalization is similarly important in order to: acknowledge the ideological differences and inequalities between international partners; question the hegemony, ethnocentricity, and paternalism in the Global North-South encounters; examine the colonial legacy of partnering institutions and systems; and safeguard collaborations against self-serving agendas and easy solutions (Andreotti, 2015). This program of action specifically targets the neoliberal citizen-subject configured as a white economic actor, by opening it to multiple subjectivities and exposing the asymmetries of power among them. Also in order is a critical evaluation of the social science discourses and tools that were used to install the white experience as the norm of scientific knowledge and U.S. citizenship.

\section{CONCLUDING THOUGHTS}

In the United States, as in many other western nations, the neoliberal biopolitics of race judges white subjects as worthy of protection and reproduction and relies on science to demonstrate the deficits of other races and ethnicities. Under the guise of cultural difference, racism patrols the boundaries of the academic profession, reinforces white dominance through socialization, and regulates the assignment of merit and value. As a leader in internationalization and a dominant economic actor in the global educational market, U.S. higher education is a potent agent of dissemination of western innovative ideas and practices premised on the superiority of white heritage, culture, and progress. The COVID pandemic and the Black Lives Matter movement expose the problematic and injurious nature of that heritage and normative whiteness, whose protection, according to Foucault, requires constant vigilance and subjugation of others and, in Mbembe's analysis, leads to necropolitics of illness and death of people of color. It is ironic, although unsurprising, that despite their well-publicized commitment to diversity and social justice, a vast majority of U.S. higher education institutions and communities have not begun a systematic critique of their own involvement in white supremacy. Similarly, in the field of internationalization, after a period of constrained international travel due to COVID-19, universities eschew difficult conversations about knowledge, power, and colonialism in favor of the old commercial models of internationalization (Rizvi, 2020).

Despite its tragic consequences, the "double pandemic" of COVID-19 and racism forces colleges and universities to explore new imaginaries, worldviews that make some futures possible while precluding others (Kamola, 2014). The time for such imaginings is ripe at present when the wave of protests against racial injustice have amplified the voices of scholars critical of the neocolonial and 
neoliberal foundations of higher education and the debates about immigration, U.S. census, and voting rights have showed the contested nature of American citizenship.

Lastly, the newly developed COVID-19 vaccines present a new biopolitical challenge for U.S. colleges and universities that have to categorize the lives of their students and employees in order of their vulnerability and importance for organizational operations and functioning. At the same time, the stories of the vaccine development demonstrate a positive role of U.S. higher education in the global mobilization of science in the service of all humanity. A decade ago, universities' drive to internationalize for increased competitiveness, revenues, and branding firmly eclipsed the values of cooperation, peace, and mutual understanding (de Wit, 2020). The global effort to create a COVID-19 vaccine highlighted a temporary reversal of institutional priorities. The race for the vaccine, international collaboration, and the global deployment of scientific tools and expertise in search of a cure exemplifies what Robert Esposito would call an affirmative biopolitics for the common good (Esposito, 2012). Esposito, who theorizes immunity as protection of individual and collective life, is interested in positive, rather than repressive, aspects of biopolitics. This line of thinking opens up a new and perhaps, more optimistic view of U.S. universities' and laboratories' engagement with biopower. After the analysis of the harmful effects of neoliberal biopolitics of race, the next question may very well be: how do U.S. institutions of higher education engage in the preservation of life and health of communities, people, society, and the environment? And perhaps, more importantly, how do they do so in the context of global biopolitics that includes the necropolitical move by wealthy nations to hoard the vaccine doses, leaving millions in the Global South exposed to the risk of the contagion, disease, and death (BBC News, 2020, December 9)? Not just an inquiry, this question is an ethical imperative to work for the public good.

\section{REFERENCES}

Ahlquist, R. (2011). The "Empire" strikes back via a neoliberal agenda: Confronting the legacies of colonialism. Counterpoints, 402, 9-32.

Allen, L. and Rasmussen, M. L. (2015). Queer conversation in straight spaces: An interview with Mary Lou Rasmussen about queer theory in higher education. Higher Education Research and Development, 34(4), 685-694. https://doi.org/10.1080/07294360.2015.1062072

Andreotti, V. O. (2015). Global citizenship education otherwise. In A. A. Abdi, L. Shulz, and T. Pillay (Eds.), Decolonizing global citizenship education (pp. 221229). Sense Publishers.

Andreotti, V. O., Stein, S., Ahenakew, C., \& Hunt, D. (2015). Mapping interpretations of decolonization in the context of higher education. Decolonization: Indigeneity, Education, \& Society, 4(1), 21-40.

Ansley, F. L. (1997). Race and the core curriculum in legal education. In J. Stefancic and R. Delgado (Eds.), Critical white studies: Looking behind the mirror (pp. 214-219). Temple University. 
American Psychological Association. (2020, May 29). "We are living in a racism pandemic," says APA President.

https://www.apa.org/news/press/releases/2020/05/racism-pandemic

Apata, G. O. (2020). "I can't breathe": The suffocating nature of racism. Theory, Culture \& Society. https://doi.org/10.1177/0263276420957718

Bazzul, J. (2017). Biopolitics and the "subject" of labor in science education. Cultural Studies of Science Education, 12, 873-887. https://doi.org/10.1007/s11422-017-9840-2

BBC News. (2020, December 9). Rich countries hoarding Covid vaccines, says People's Vaccine Alliance. https://www.bbc.com/news/health-55229894

Blanco Ramirez, G. (2014). Trading quality across borders: Colonial discourse and international quality assurance policies in in higher education. Tertiary Education and Management, 20, 121-134. https://doi.org/10.1080/13583883.2014.896025

Bowman, B. (2020). On the biopolitics of breathing: Race, protests, and state violence under the global threat of COVID-19. South African Journal of Psychology, 50(3), 312-315.

Bourassa, G. (2011). Rethinking the curricular imagination: Curriculum and biopolitics in the age of neoliberalism. Curriculum Inquiry, 41(1), 5-16.

Bourassa, G. (2019). Educational biopolitics, innovation, and social reproduction. In M. Peters and R. Heraud (Eds.), Encyclopedia of educational innovation (pp. 1-6). Springer. https://doi.org/10.1007/978-981-13-2262-4_114-1

Brandzel, A. L. (2016). Against citizenship: The violence of the normative. The University of Illinois Press.

Brown, S. and Najmabadi, S. (2017, January 27). Shock, despair, and outrage: Academics condemn Trump's immigration crackdown. The Chronicle of Higher Education. http://www.chronicle.com/article/Shock-DespairOutrage$/ 239041$

Buckner, E. (2019). The internationalization of higher education: National interpretations of a global model. Comparative Education Review, 63(3), 315336.

Buckner, E. and Stein, S. (2019). What counts as internationalization? Deconstructing the internationalization imperative. Journal of Studies in International Education, 24(2), 151-166. https://doi.org/10.1177/1028315319829878

Cabrera, N. L. (2020). "Never forget" the history of racial oppression: Whiteness, white immunity, and educational debt in higher education. Change: The Magazine of Higher Learning, 52(2), 37-40. https://doi.org/10.1080/00091383.2020.1732774

Cabrera, N. L., Franklin, J. D., \& Watson, J. S. (2017). Whiteness in higher education: The invisible missing link in diversity and racial analyses: ASHE higher education report, 42(6). Wiley.

Cary, L. J. (2001). The refusals of citizenship: Normalizing practices in social educational discourses. Theory and Research in Social Education, 29(3), 405430. https://doi.org/10.1080/00933104.2001.10505949 
Chatterjee, P. and Maira, S. (2014). The imperial university: Race, war, and the nation-state. In P. Chatterjee and S. Maira (Eds.), The imperial university: Academic repression and scholarly dissent (pp. 1-50). University of Minnesota Press.

Deem, R., Mok,K. H., \& Lucas, L. (2008). Transforming higher education in whose image? Exploring the concept of the "world-class" university in Europe and Asia. Higher Education Policy, 21, 83-97.

Demetri, F. (2020, March 21). Biopolitics and coronavirus, or don't forget Foucault. Naked Punch. http://www.nakedpunch.com/articles/306

De Wit, H. (2020). Internationalization of higher education: The need for a more ethical and qualitative approach. Journal of International Students, 10(1), i-iv.

Dixon-Román, E. J. (2017). Regenerative capacities: New materialisms, inheritance, and biopolitical technologies in education policy. Equity and Excellence in Education, 50(4), 434-445. https://doi.org/10.1080/10665684.2017.1399098

D'Hoest, F. and Lewis, T. E. (2015). Exhausting the fatigue university: In search of a biopolitics of research. Ethics and Education, 10(1), 49-60. https://doi.org/10.1080/17449642.2014.998023

Done, E. J. (2015). Mandatory accreditation for Special Educational Needs Coordinators: Biopolitics, neoliberal managerialism and the Deleuzo-Guattarian "war machine." Journal of Education Policy, 30(1), 86-100.

Douglas-Gabriel, D. (2020, August 4). "The kids will forget": Custodians, housekeepers and other support staff brace for college reopenings. The Washington Post. https:/www.washingtonpost.com/education/2020/08/04/kids-will-forgetcustodians-housekeepers-other-support-staff-brace-college-reopenings/

Dutta, M. J. (2020). Whiteness, internationalization, and erasure: Decolonizing futures from the Global South. Communication and the Critical/Cultural Studies, 17(2), 228-235. https://doi.org/10.1080/14791420.2020.1770825

Ellis, L. (2020, April 28). How the Coronavirus might-or might not-slow research universities' ambitions. The Chronicle of Higher Education. https://www.chronicle.com/article/How-the-Coronavirus-Might-/248650

Erbsen, H. (2018). The biopolitics of international exchange: International education exchange programs - facilitator or victim in the battle for biopolitical normativity? Russian Politics, 3(1), 68-87.

Esposito, R. (2012). Community, immunity, biopolitics. Política común, 3. http://dx.doi.org/10.3998/pc.12322227.0003.001

Esposito, R. (2020, February 28). Cured to the bitter end. European Journal of Psychoanalysis. http://www.journal-psychoanalysis.eu/coronavirus-andphilosophers/?fbclid=IwAR1 wyD5z7iP8MjqXkJXDifNaZ7qBZSavluXT53a NMWiwJfFTOzoGf 2sCL8

Evans-Winters, V. E. (2017). Necropolitics and education. In G. Sirrakos and C. Emdin (Eds.), Between the world and the urban classroom (pp. 19-33). SensePublishers. https://doi.org/10.1007/978-94-6351-032-5

Fiaccadori, E. (2015). State racism and the paradox of biopower. Foucault Studies, $19,151-171$. 
Foucault, M. (1975-1976/2003). Society must be defended: Lectures at the College de France, 1975-76 (David Macey, Trans.). Picador.

Foucault, M. (1977-1978/2007). Security, territory, population: Lectures at the College de France, 1977-1978 (Michel Senellart, Ed. and Graham Burchell, Trans.). Palgrave Macmillan.

Giroux, H. A. (2006). Reading Hurricane Katrina: Race, class, and the biopolitics of disposability. College Literature, 33(3), 171-196.

Giroux, H. A. (2008). Beyond the politics of disposability: Rethinking neoliberalism in the New Gilded Age. Social Identities, 14(5), 587-620.

Gonzales-Brambila, C. N., Reyes-Gonzales, L., Veloso, F., and Peres-Agnon, M. A. (2016). The scientific impact of developing nations. PLoS One, 11(3). https://doi.org/10.1371/journal.pone.0151328

Gyamera, G. O. and Burke, P. J. (2018). Neoliberalism and curriculum in higher education: A post-colonial analysis. Teaching in Higher Education, 23(4), 450467. https://doi.org/10.1080/13562517.2017.1414782

Harvard T. H. Chan School of Public Health. (2020, October 29). Innovating on campus: Supporting mental health of students of color during COVID-19 and beyond. https://www.youtube.com/watch? $=$ XRJIGOaOwtE

Hayes, A. (2020). Epistemic democracy and international students. Journal of International Students, 19(2). https://doi.org/10.32674/jis.v10i2.1968

Hoeg, D. and Bencze, L. (2017). Rising against a gathering storm: A biopolitical analysis of citizenship in STEM policy. Cultural Studies of Science Education, 12, 843-861. https://doi.org/10.1007/s11422-017-9838-9

Hope, A. (2014). Biopower and school surveillance technologies 2.0. British Journal of Sociology of Education, 37(7), 885-904. https://doi.org/10.1080/01425692.2014.1001060

Howell, A. and Richter-Montpetit, M. (2019). Racism in Foucauldian security studies: Biopolitics, white war, and whitewashing of colonial and racial violence. International Political Sociology, 13, 2-19.

Johnson, E. and Patel, V. (2020, August 19). How Covid-19 united the higher-ed work force. The Chronicle of Higher Education. https://www.chronicle.com/article/how-covid-19-united-the-higher-ed-workforce

Johnson, K. A. C. (2020). $21^{\text {st }}$ century international higher education hotspots: International student mobility growth in nontraditional destination countries. Journal of International Education, 10(1), https://doi.org/10.32674/jis.v10i1.1851

Johnstone, M. and Lee, E. (2020). Education as a site for the Imperial project to preserve whiteness supremacy from the colonial era to the present: A critical analysis of international education policy in Canada. Whiteness and Education, 1-17. https://doi.org/10.1080/23793406.2020.1784038

Kamola, I. (2014). US universities and the production of the global imaginary. The British Journal of Politics and International Relations, 16(3), 515-533.

Karter, J. M., Robbins, B. D., and McInerney, R. G. (2020). Student activism in the neoliberal university: A hermeneutic phenomenological analysis. Journal of Humanistic Psychology, 1-30, https://doi.org/10.1177/0022167819834751 
Kearl, B. (2019). Special education as neoliberal property: The racecraft, biopolitics, and immunization of disability. Educational Studies, 55(4), 473-488. https://doi.org/10.1080/00131946.2019.1630126

Kidman, J. (2020). Whither decolonization? Indigenous scholars and the problem of inclusion in the neoliberal university. Journal of Sociology, 56(2), 247-262.

Kim, J. (2020, April 1). Teaching and learning after COVID-19. Inside Higher Ed. https://www.insidehighered.com/digital-learning/blogs/learninginnovation/teaching-and-learning-after-covid-19

Knight, J. (2004). Internationalization remodeled: Definition, approaches, and rationales. Journal of Studies in International Education, 8(1), 5-31.

Land, M. \& Libal , K. (2017, January 31). Trump is undermining higher education as a global enterprise. The Chronicle of Higher Education. https://www.chronicle.com/article/Trump-Is-Undermining-Higher/239060

Latour, B. (2020, March 26). Is this a dress rehearsal? Critical Inquiry. https://critinq.wordpress.com/2020/03/26/is-this-a-dress-rehearsal/

Lee, S., \& Waters, S. F. (2020). Asians and Asian Americans' experiences of racial discrimination during the COVID-19 pandemic: Impacts on health outcomes and the buffering role of social support. Stigma and Health. http://dx.doi.org/10.1037/sah0000275

Lewis, T. E. (2009). Education and the immunization paradigm. Studies in Philosophy and Education, 28, 485-498._https://doi.org/10.1007/s11217-0099140-8

Litam, S. D. A. (2020). "Take your kung-fu back to Wuhan": Counseling Asians, Asian Americans, and Pacific Islanders with race-based trauma related to COVID-19. The Professional Counselor, 10(2), 144-156. https://doi.org/10.15241/sdal.10.2.144

Lorenzini, D. (2020, April 2). Biopolitics in the time of coronavirus. Critical Inquiry. https://critinq.wordpress.com/2020/04/02/biopolitics-in-the-time-ofcoronavirus/

Mangan. K. (2020, June 8). After years of delays, colleges are quickly acting on protesters' demands. The Chronicle of Higher Education. https://wwwchronicle-com.proxy.lib.ohio-state.edu/article/After-Years-ofDelays/248949?cid=wcontentgrid_hp_4

Mbembe, A. (2003). Necropolitics. Public Culture, 15(1), 11-40.

McGuire, P. (2021, January 8). Colleges share blame for assault on democracy. Chronicle of Higher Education. https://www.chronicle.com/article/collegesshare-the-blame-for-assault-on-democracy

McWhorter, L. (2010). Racism and bipower. In R. Martinez (Ed.), On race and racism in America: Confessions in philosophy (pp. 55-85). Pennsylvania State University Press.

Mignolo, W. (2011). The darker side of western modernity: Global futures, decolonial options. Duke University Press.

Mitchell, D. E., and Nielsen, S. Y. (2012). Internationalization and globalization in higher education. In H. Cuadra-Montiel (Ed.), Globalization -Education and management agendas (pp. 3-22), https://doi.org/10.5772/48702

Moses, M., Maeda, D. J., and Paguyo, C. H. (2017). Racial politics, resentment, and 
affirmative action: Asian Americans as "model" college applicants. Journal of Higher Education, 90(1),

$1-26$. https://doi.org/10.1080/00221546.2018.1441110

Naidoo, R. (2011). Rethinking development: Higher Education and the new imperialism In R. King, S. Marginson, and R. Naidoo (Eds.), Handbook on globalization and higher education (pp. 40-58). Edward Elgar Publishing.

Nakayama, T. K. (2020). Whiteness is not contained. Communication and Critical/Cultural Studies, $\quad 17(2), \quad 199-201$. https://doi.org/10.1080/14791420.2020.1770821

Olssen, M. (2004). Foucault and Marxism: Rewriting the theory of historical materialism. Policy Futures in Education, 2(3-4), 454-482.

Olssen, M. and Peters, M. A. (2005). Neoliberalism, higher education, and the knowledge economy: From the free market to knowledge capitalism. Journal of Education Policy, 20(3), 313-345.

Open Doors. (2020). Annual release. https://opendoorsdata.org/annual-release/

Patel, L. (2014). Countering coloniality in educational research: From ownership to answerability. Educational Studies, 50(4), 357-377. https://doi.org/10.1080/00131946.2014.924942

Phillips, D. K. and Nava, R. Ch. (2011). Biopower, disciplinary power, and the production of "the good Latino/a teacher." Discourse: Studies in the Cultural Politics of Education, 32(1), 71-83. https://doi.org/10.1080/01596306.2011.537074

Pineda, P., Gregorutti, G., \& Streitwieser, B. (2020). Emerging decolonized research collaboration: The Max Planck Society and the Leibnitz Associate in Latin America. Journal of Studies in International Education, 24(1), 59-78. https://doi.org/10.1177/1028315319888891

Reid, J. (2005). The biopolitics of the war on terror: The critique of the 'return of imperialism' thesis in international relations. Third World Quarterly, 26(2), 237-252.

Rizvi, F. (2020). Reimagining recovery for a more robust internationalization. Higher Education Research \& Development, 39(7), 1313-1316.

Ritter, Z. S. and Roth, K. R. (2021). International students need not apply: Impact of the US immigration policy in the Trump era on international student enrollment and campus experiences. In K. R. Roth and Z. S. Ritter (Eds.), Whiteness, power, and resisting change in US higher education (pp. 77-101). Pelgrave. https://doi.org/10.1007/978-3-030-57292-1_5

Ruglis, J. (2010). Mapping the biopolitics of school dropout and youth resistance. International Journal of Qualitative Studies in Education, 24(5), 627-637.

Sevage, L. (2009). The scholarship of teaching and learning and the neoliberalization of higher education: Constructing the "entrepreneurial learner." Canadian Journal of Higher Education, 39(2), 24-44.

Shahjahan, R. A. (2011). Decolonizing the evidence-based education and policy movement: Revealing the colonial vestiges in educational policy, research, and neoliberal reform. Journal of Education Policy, 26(2), 181-206. https://doi.org/10.1080/02680939.2010.508176

Singh, M., Gray, T., Hall, T., \& Downey, G. (2018). Globalizing higher education 
policy practice: Internationalizing education through learning transformations in knowledge construction. In T. Hall, T. Gray, G. Downey, and M. Sing (Eds.), The globalization of higher education (pp. 445-460). Palgrave Macmillan. https://doi.org/10.1007/978-3-319-74579-4_27

Sliwa, M., Meier Sorensen, B., and Cairn, J. (2015). "You have to choose a novel": The biopolitics of critical management education. Management Learning, 46(3), 243-259.

Sonu, D. (2020). Making a racial difference: A foucauldian analysis of school memories told by undergraduate students of color in the United States. Critical Studies in Education, https://doi.org/10.1080/17508487.2020.1763415.

Stein, S. (2017). Internationalization for an uncertain future: Tensions, paradoxes, and possibilities. The Review of Higher Education, 41(1), 3-32.

Stein, S. (2018). Racialized frames of value in U.S. university responses to the travel ban. ACME: An International Journal for Critical Geographies, 17(4), 893919.

Stein. S. (2020). A colonial history of the higher education present: Rethinking landgrant institutions through processes of accumulation and relations of conquest. Critical Studies in Education, 61(2), 212-228. https://doi.org/10.1080/17508487.2017.1409646

Stein, S. and Andreotti, V.O. (2017). Higher education and the modern/colonial imaginary. Cultural Studies-Critical Methodologies, 17(3), 173-181. https://doi.org/10.1177/1532708616672673

Streitwieser, B., Loo, B., Ohorodnik, M, \& Jeong, J. (2019). Access for refugees into higher education: A review of interventions in North America and Europe. Journal of Studies in International Education, 23(4), 473-496. https://doi.org/10.1177/1028315318813201

Squire, D., Williams, B.C., and Tuitt, F. (2018). Plantation politics and neoliberal racism in higher education: A framework for reconstructing anti-resist institutions. Teacher's College Record, 120, 1-20.

Sperduti, V. R. (2017). Internationalization as westernization in higher education. Comparative \& International Education, 9, 9-12.

Suspitsyna, T. (2015). Cultural hierarchies in the discursive representations of China in the Chronicle of Higher Education. Critical Studies in Education, 56(1), 2137.

Suspitsyna, T. and Shalka, T. (2019). The Chinese international student as a (post)colonial other: An analysis oof cultural representations in a US media discourse. Review of Higher Education, 42S, 287-308. http://doi.org/10.1353/rhe.20190053

Taylor, B. J., Cantwell, B., Watts, K., and Woods, O. (2019). Partisanship, white racial resentment, and state support for higher education. Journal of Higher Education, 91(6), 858-887. https://doi.org/10.1080/00221546.2019.1706016

Todoran, C. and Peterson, C. (2020). Should they stay or should they go? How the 2017 U.S. Travel Ban affects international doctoral students. Journal of Studies in International Education, 24(4), 440-455. https://doi.org/10.1177/1028315319861344 
Wallsten, K., Nteta, T. M., McCarthy, L. A., and Tarsi, M. R. (2017). Prejudice or principled conservatism? Racial resentment and white opinion toward paying college athletes. Political Research Quarterly, 70(1), 209-222. https://doi.org/10.1177/1065912916685186

Webel, M. (2020, March 25). Calling COVID-19 a 'Chinese virus" is wrong and dangerous - the pandemic is global. The Conversation. https://theconversation.com/calling-covid-19-a-chinese-virus-is-wrong-anddangerous-the-pandemic-is-global-134307

Winnubst, S. (2020). The many lives of fungibility: Anti-blackness in neoliberal times. Journal of Gender Studies, 29(1), 102-112. https://doi.org/10.1080/09589236.2019.1692193

World Health Organization. (2020). Global research on coronavirus disease (COVID-19). https://www.who.int/emergencies/diseases/novel-coronavirus2019/global-research-on-novel-coronavirus-2019-ncov

Wuest, J. (2020, April 16). The state of biopower in the age of coronavirus. Debates. http://thephilosophicalsalon.com/the-state-of-biopower-in-the-age-of-thecoronavirus/

Yakaboski, T. and Perozzi, B. (2018). Internationalizing US student affairs practice: An intercultural and inclusive framework. Routledge.

Zapp, M. and Lerch, J. C. (2020). Imagining the world: Conceptions and determinants of internationalization in higher education curricula worldwide. Sociology of Education, 372 93(4), https://doi.org/10.1177/0038040720929304

Zembylas, M. (2020). Necropolitics and sentimentality in education: The ethical, political and pedagogical implications of "making live and letting die" in the current political climate. Pedagogy, Culture \& Society, 1-16. https://doi.org/10.1080/14681366.2020.17447108

TATIANA SUSPITSYNA, $\mathrm{PhD}$, is an Associate Professor in the Department of Educational Studies at the Ohio State University. Her major research interests lie in the area of internationalization of higher education, discourse analysis, governmentality, and organizational studies of higher education. Email: suspitsyna.1@osu.edu 